\title{
Discussion on Railway Vocation Professional Etiquette Education Mode
}

\author{
Meiling XU \\ Liuzhou Railway Vocational Technical College, Liuzhou, 545007, China \\ Email: xumeiling109@163.com
}

Keywords: Professional Etiquette, Education Mode, Vocational Technical Colleges

\begin{abstract}
This is an educational art by designing teaching situations cleverly to improve teaching effectiveness. It has many advantages in politics class. Politics teachers can use a variety of materials cleverly to create teaching situation. In order to create a valuable teaching situation, teachers must master the principles of the creation of teaching situation.
\end{abstract}

\section{Introduction}

The Significance of Profession Etiquette Education

Chinese is known as "the nation of rites" with a history of thousands of years. It breeds the noble system and formal a series of perfect manners gradually. As a kind of culture, etiquette is rituals of human social activities. It also reflects a country's most important and essential of soft power to a person 、 a country and a nation's quality.

Professional etiquette is not only an important part of etiquette, but also a kind of nurturance. It helps staffs use international skills to improve performance and enhance competitiveness. The higher education should focus its efforts on students synthesizes the professional accomplishment.Practice teaching proves that, professional etiquette plays an irreplaceable role in cultivating students' vocational ability and quality. Liuzhou Railway Vocational Colleges is responsible for training thousands of railway first line cultivate high-quality skilled personnel, who be able to handle the work of industry production, service and management. The training should be in accordance with the need of railway service industry jobs, strengthen and attach importance to the students' professional etiquette education to make they master people's-behavior, workplace-manners, service standards and ability of dealing with after-sale disputes. That cultivate students to be elegant, decent, high-quality comprehensive talent with interpersonal communication skill, to better suit the needs of the future service.

\section{Establish Professional Etiquette Education Concept}

Education concept guide and restrict training practice. In the training practice, etiquette education cause is design to developing individuals, which is based on the actual status of college students and their specialty, align around the mission of college's talent cultivation ,take the scientific development concept ad the instruction, build up the scientific practice-creative theory, break though the constraint of conventional teaching theory, to cultivate students' innovative and practice abilities, fulfill the cultivation of all-rounded talents.

\section{A Profession Education Concept of Creating Goodwill and Rearing People}

The most important quality of talented is courtesy, that college education's fundamental task is creating goodwill and rearing people. Therefore, etiquette education should be the support of professional personnel training, enhance the effectiveness of education practically, train the students to have the right attitude , good service consciousness 、 the spirit of innovation and good quality of personality cultivation.

\section{A Profession Education Concept of Servicing Firms}

Who is charge with the mission of training high-quality talents for railway firms, railway vocational technical colleges should set etiquette education course as specialized course. By learning professional etiquette manners and skill ,It makes college students master how to be a self-discipline, 
modest people, and how to respect people 、 sincerely treat people and make their behavior civilized, as well as spoken, polite, elegant. At the same time, it further promotes the comprehensive development of students' knowledge, ability, quality, that show students' personal charm better in the service and the interpersonal communication.

\section{Profession Education Concept in a Vivid and Novel Way}

Reform and innovation makes etiquette education energetic and efficient. Vivid and effective teaching practice break the traditional pattern though many kinds teaching models organic synthesis, like simulation training network platform and role-interaction between the relationship of in class-out of class 、 on campus-off campus 、 teacher-student, makes knowledge easy to understand 、 vivid、novel、 lively v solid and convenience, more interesting and more appealing.

\section{Build a Profession Etiquette Education Mode}

Railway Vocational Colleges are responsible for training thousands of railway first line, cultivating high-quality skilled personnel, who are able to handle the work of industry production, service and management. The training should be in accordance with the need of railway service industry jobs, attach and strengthen the students' professional etiquette education, so that the students posses a certain theoretical knowledge and etiquette culture, interpersonal skills and professional ability of communication, organization, coordination, etc. Measures of strengthen profession etiquette education:

\section{Set Profession Etiquette Education Course as Specialized Course}

Profession etiquette education covers Chinese culture education and moral education, better directly teaching students how to deal with people, how to be a civilized person. Therefore, railway vocational technical colleges should set etiquette education course as specialized course to spreading and popularizing. At railway important positions, railway vocational technical college's graduates are in the highest proportion. So, who are charge with the mission of training high-quality talents for railway firms, railway vocational technical colleges should emphasize the education since the first day of the study. By etiquette training and behavioral training to make students comprehend the basic ideas of profession etiquette and how to use it. It can effectively improve their ideological level of civility and mental outlook, mold and cultivate their inner character and self-culture. All above improvement could be seen from the way students' move and talk, make them have a noble moral personality and high culture level.

\section{Integrate Profession Etiquette Education to Behavioral Training}

Conducting etiquette training is the key of strengthening etiquette application ability and important means to develop occupation accomplishment behavior. Raising the etiquette application ability can not only depend on the knowledge of learning theory or empty talk, it is more involved in the operation and training by students. During the training, we should fully mobilize the enthusiasm of interacting among students' learning, develop the spirit of team cooperation and cultivating students' expressive force and creativity. It is necessary to offer opportunities for students to learn etiquette in doing and practice etiquette in learning, at the same time, students learn to cooperate and be an upright person.

\section{Integrate Profession Etiquette Education to Activities in and out of Class}

There is a common phenomenon in the etiquette education of Higher Vocational colleges: During the students' progress obviously, improve rapidly in the etiquette course, but with the end of the course and the passage of time, the students have no specific environment and supervision, they gradually return to the state before learning etiquette. Therefore, the classroom teaching and extracurricular activities combined to create a good atmosphere of learning etiquette and pay attention to etiquette is very necessary. It can give full play to the initiative of the students, creative and independent, emphasizes the mutual cooperation and personality development, teaching practice in accordance with the rules of higher vocational education, is to learn in order to practice etiquette teaching another embodiment. This practice makes the etiquette education closer to the students, so 
that more teachers and students participate in learning etiquette, good manners climate and atmosphere are formed on campus, to achieve the purpose of learning in order to practice. So, the combination of classroom teaching and extracurricular activities is important to support the etiquette education in Higher vocational college. In our teaching practice, advocated "from the practice, to practice", to "start small, start from now on, begin from me" for the idea, encourage students based on the campus, extending to the society under the conditions allowing, actively participate in extracurricular activities and social practice. Such as the organization of students participate in volunteer, internship and public welfare activities, etc. Enable the students to integrate theory with practice when practicing, understand the social reality, the unity of knowledge and action. Let the students feel the atmosphere of the occupation in the real work environment, feel the occupational spirit, so as to strengthen the knowledge, occupation awareness and occupation ethics training, and through personal practice, enhance the practical ability of students, improve students' occupation ethics, occupation accomplishment and act toward others etiquette skills.

\section{Including Occupational Etiquette to Railway Post Practice Examination Content}

Only through practice etiquette, we can truly feel and understand education railway occupation. We must let the students thoroughly working in railway window position, the students experience facing the real object of service and how to use the occupation service etiquette in the railway work environment, and organizing students to use cold and summer vacation and internship to the railway enterprise post practice is the most effective way.

In the practice examination, we can separate the students professional skills practice and occupation etiquette practice to assessment, for the railway service professionals such as railway transportation management, we can set the etiquette standard of occupation etiquette practice examination, such as the times of passenger praising and complaining, bring the railway service the specific job etiquette reflected into the examination, so as to strengthen the knowledge, make students experience the core connotation of railway service, culture, occupation morality and etiquette literacy feelings as the railway in the future occupation people should have.

\section{Conclusion}

Establish occupation etiquette website railway service etiquette learning platform. Open up a multimedia network course website of setting teaching, learning, play, courtesy, teaching video and animation as a whole named "rail transit service etiquette", website URL is: http://222.217.36.199/gdly/, called the "rail transportation industry, service etiquette course". according to our college students professional post demand, the site project the mode that "guide study by post", the link of professional etiquette teaching, situational teaching methods highlight act etiquette; the autonomous learning and interactive communication atmosphere, make the site become occupation etiquette education in higher vocational colleges. The medium and carrier, become assistant of occupation etiquette education; a greater degree of servicing for students, it builds a space for students learning etiquette, it can also be a stage for the students to display their talent and foster self-confidence, and a terrace for students intend to enhance the platform in the future occupation of sustainable development ability of service work, make the teaching occupation etiquette education closer to the students' interpersonal and occupation of the future, strengthens students' temperament training and conservation practice, strengthens etiquette application ability, to engage in service work to lay a solid foundation for students.

If you follow the "checklist" your paper will conform to the requirements of the publisher and facilitate a problem-free publication process.

\section{References}

[1] Zhang Yansong, Vocational College etiquette Course Practice Teaching [J]Occupation Education Research.2007-11 
[2] Jin Zhiying, Service Etiquette Teaching to Cultivate Students' Occupation Ability of Exploration [J]Occupation Education Research, 2008-10

[3] Li Xiaoyi, A Preliminary Study on the Etiquette Education Mode of Higher Vocational

University. [M]2006-11

[4] TSE tin, College Students Occupation Quality Cultivation and Employment Guidance [M]Beijing: Tsinghua University press, 2007-March

[5] Sun Yumei, Teaching Situational Simulation Practical Etiquette Teaching [J].Journal of Yanbei Normal College, 2006-06 